\title{
(2) OPEN ACCESS \\ Practice of endoscopy during COVID-19 pandemic: position statements of the Asian Pacific Society for Digestive Endoscopy (APSDE-COVID statements)
}

\author{
Philip Wai Yan Chiu 다, ${ }^{1}$ Siew C Ng 0 (1), ${ }^{2}$ Haruhiro Inoue, ${ }^{3}$ D Nageshwar Reddy, ${ }^{4}$ \\ Enqiang Ling $\mathrm{Hu}_{1}{ }^{5}$ Joo Young $\mathrm{Cho}^{6}$ Lawrence $\mathrm{KY} \mathrm{Ho},{ }^{7}$ David G Hewett (1), ${ }^{8,9}$ \\ Han-Mo Chiu $\odot{ }^{10}{ }^{10}$ Rungsun Rerknimitr, ${ }^{11}$ Hsiu-Po Wang, ${ }^{12}$ Shiaw Hooi Ho, ${ }^{13}$ \\ Dong Wan Seo, ${ }^{14}$ Khean-Lee Goh, ${ }^{15}$ Hisao Tajiri, ${ }^{16,17}$ Seigo Kitano, ${ }^{18}$ \\ Francis K L Chan (1) ${ }^{2}$
}

For numbered affiliations see end of article.

\section{Correspondence to Professor Siew C Ng, Department of Medicine and Therapeutics, Institute of Digestive Disease, State Key Laboratory of Digestive Disease, LKS Institute of Health Sciences, The Chinese University of Hong Kong, Hong Kong, Hong Kong; siewchienng@cuhk.edu.hk}

SK and FKLC are joint senior authors.

Received 22 March 2020 Revised 25 March 2020 Accepted 25 March 2020 Published Online First 2 April 2020

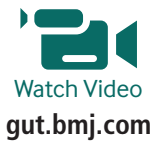

Check for updates

(C) Author(s) (or their employer(s)) 2020. Re-use permitted under CC BY-NC. No commercial re-use. See rights and permissions. Published by BMJ.

To cite: Chiu PWY, Ng SC, Inoue $\mathrm{H}$, et al. Gut

2020;69:991-996

\section{ABSTRACT}

Coronavirus-19 (COVID-19) caused by SARS-CoV-2 has become a global pandemic. Risk of transmission may occur during endoscopy and the goal is to prevent infection among healthcare professionals while providing essential services to patients. Asia was the first continent to have a COVID-19 outbreak, and this position statement of the Asian Pacific Society for Digestive Endoscopy shares our successful experience in maintaining safe and high-quality endoscopy practice at a time when resources are limited. Sixteen experts from key societies of digestive endoscopy in Asia were invited to develop position statements, including patient triage and risk assessment before endoscopy, resource prioritisation and allocation, regular monitoring of personal protective equipment, infection control measures, protective device training and implementation of a strategy for stepwise resumption of endoscopy services after control of the COVID-19 outbreak.

\section{INTRODUCTION}

In the past 3 months, a new coronavirus of SARS-CoV-2, leading to coronavirus disease 2019 (COVID-19), has been rapidly disseminated throughout Asia. ${ }^{1}$ The World Health Organization (WHO) declared COVID-19 as pandemic on 11 March 2020, and by 24 March 2020 the number of confirmed COVID-19 cases had increased to more than 372000 globally. $^{2}$ A cohort study on 1099 patients with COVID-19 from Wuhan showed that typical clinical symptoms included cough and sputum, sore throat, fever, fatigue, and shortness of breath. ${ }^{3}$ More than $40 \%$ of patients had contact history and $56.2 \%$ had no raised temperature. Gastrointestinal symptoms are not uncommon and $5 \%$ of patients had nausea or vomiting and $3.8-10.1 \%$ had diarrhoea. ${ }^{4}$ The overall mortality was $1.4 \%$, and for those with severe disease the mortality was $22.4 \% .^{356}$

Although there are no data on whether endoscopy is an aerosol-generating procedure, positive insufflation during endoscopic procedures could pose a risk of generating aerosol and increase the risk of SARS-CoV-2 transmission. Healthcare providers of endoscopy therefore are facing tremendous risk during the pandemic of COVID-19 as the spread is mainly through direct contact or aerosol droplets, and endoscopy procedures require a short physical distance between patients and personnel. A study performed during the SARS outbreak in 2003 showed that droplets from infected patients could reach people located two metres or more from the source. ${ }^{7}$ In addition, experience from the SARS epidemics demonstrated the presence of coronavirus in stool samples and intestinal biopsy samples. ${ }^{8}$ Recently, it has been confirmed that COVID-19 can be found in the oral cavity and faecal samples of infected individuals. ${ }^{9-12}$

To date, joint new guidance on the practice of endoscopy has been posted by the American College of Gastroenterology and the British Society of Gastroenterology. ${ }^{1314}$ Contrary to western countries, Asia has already accumulated substantial experience in combating the COVID-19 outbreak; some regions have shown their ability to prevent outbreaks and maintain a high-quality endoscopy service without subjecting patients and staff to undue health hazards.

The Asian Pacific Society for Digestive Endoscopy (APSDE) gathered experts to develop a position paper on the practice of endoscopy during the COVID-9 pandemic. The current position statements represent expert opinion and also our experience in combating this outbreak at a time when the supply of personal protective equipment is limited. Our objective is to provide recommendations for endoscopy centres on management and preventive measures during the COVID-19 pandemic. APSDE emphasises that risk management protocols should be developed according to healthcare priorities and available resources of individual centres. These statements should be considered as a framework of good clinical practice rather than a medicolegal reference.

\section{METHODS}

The lead authors (PWYC, SCN and FKLC) were appointed by APSDE to review the literature and to invite experts. and developed the position statement. The members of the writing committee were selected based on the following criteria: (1) international experts of digestive endoscopy in Asia; (2) 
Practice of endoscopy: position statements APSDE COVID-19

1. Strategies to triage and assess risk of patients with suspected or confirmed COVID-19 before endoscopy are essential.

2. Deferment of elective endoscopies should be considered until further notice during the COVID-19 outbreak.

3. Urgent endoscopies should be performed by strategically assigned staff to minimise concomitant exposure.

4. Resource reallocation for staff and medical equipment is recommended to prepare for a surge in healthcare demand.

5. Regular monitoring of supply and use of personal protective equipment (PPE) is necessary to adjust endoscopy service and uphold morale of staff.

6. Healthcare workers should practise standard infection control for endoscopy.

7. Healthcare workers should receive adequate training on gowning and removal of PPE.

8. Extra precaution is recommended during colonoscopies as prolonged faecal shedding of SARS-CoV-2 can occur.

9. Endoscopies should be performed in a negative pressure room when available with strict isolation precautions in suspected or confirmed cases of COVID-19.

10. Disinfection policy for endoscopy rooms and reprocessing of instruments should be enhanced.

11. Stepwise resumption of elective endoscopy services should be guided by control of COVID-19 in the local community, availability of manpower and equipment supply.

practical experience in restructuring or monitoring endoscopy service for the COVID-19 outbreak; (3) experience in hospital administration or crisis management.

\section{STATEMENTS}

Statement 1. Strategies to triage and assess risk of patients with suspected or confirmed COVID-19 before endoscopy are essential

During the COVID-19 pandemic, patients should be screened, triaged and risk stratified before the arrangement of endoscopy (figure 1). WHO defined a confirmed case of COVID-19 as a person with laboratory confirmation of COVID-19 infection, irrespective of clinical signs and symptoms. ${ }^{2}$ A probable case is defined as a suspected case for whom testing for COVID-19 is inconclusive. ${ }^{2}$ A suspected case is defined based on the following three criteria: (1) patients with acute respiratory illness with no other aetiology and a history of travel to, or resident in, countries reporting local transmission of COVID-19 during 14 days before symptom onset; (2) patients with acute respiratory illness who have been in contact with a confirmed or probable case of COVID-19 in the past 14 days before symptom onset and (3) patients with severe acute respiratory infection requiring hospitalisation and with no other cause that fully explains the clinical presentation. $^{2}$

Before arrival at endoscopy centres, all patients need to undergo prescreening and the following information should be collected to the best of the ability of each centre: (1) fever of more than $37.5 \mathrm{C} \mathrm{(F);} \mathrm{(2)} \mathrm{travel} \mathrm{history} \mathrm{(T);} \mathrm{(3)} \mathrm{occupational} \mathrm{exposure}$ (O); (4) contact history (C); (5) clustering (C) (FTOCC). ${ }^{15}$ The travel history should include all recent travels to countries with a high incidence of COVID-19 within the past 14 days. The occupational exposure should include those working as healthcare providers and research laboratory staff handling specimens of COVID-19. The contact history should trace those who have had recent close contact with patients with COVID-19 in the past 14 days and those who had contacts who had recently travelled to high-risk countries. The clustering represents two or more COVID-19 positive patients with a history of close contact. Any of the positive criteria for FTOCC should be regarded as a clinically suspected case, and COVID-19 testing should be conducted before any endoscopic procedure. For all suspected, probable or confirmed cases, the clinical indication for endoscopy should be reviewed, and only those with emergency or life-threatening conditions should receive endoscopy (see statement 3 ).

\section{Statement 2. Deferment of elective endoscopies should be} considered until further notice during the COVID-19 outbreak A report from Hong Kong, based on experience with SARS, showed that the risk of infection is $5 \%$ for physicians, $4 \%$ for nurses and $8 \%$ for healthcare assistants. ${ }^{16}$ The authors emphasised the importance of practising strict isolation, infection

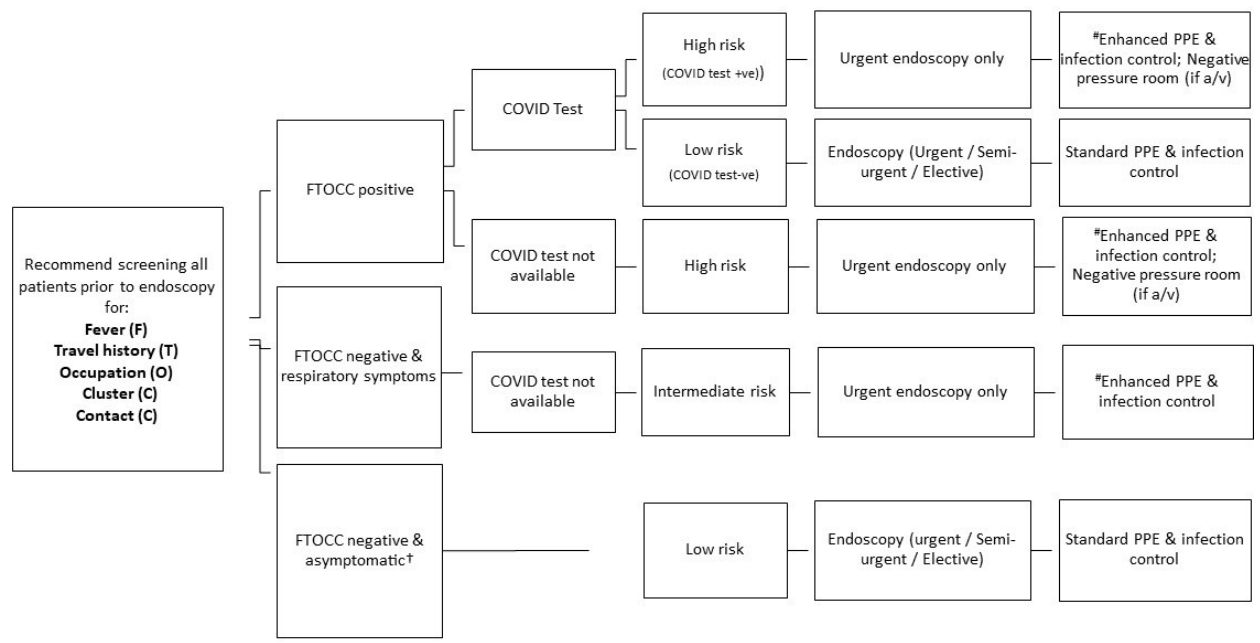

†Asymptomatic: no symptom of upper or lower respiratory tract infection;" Enhanced PPE: N95 mask, face shield, goggles, isolation gown,

disposable gloves; a/v: available

Figure 1 Flow chart to prescreen and triage patients for endoscopy during COVID-19 outbreak. PPE, personal protective equipment. 
Table 1 Classification of endoscopic procedures as urgent, semi-urgent and elective during COVID-19 outbreak

\begin{tabular}{lll}
\hline Urgent endoscopy & $\begin{array}{l}\text { Semi-urgent endoscopy (to be discussed on a case by } \\
\text { case basis) }\end{array}$ & Elective endoscopy (deferred until further notice) \\
\hline $\begin{array}{ll}\text { Acute gastrointestinal Bleeding } \\
\text { Management of perforations and leakage }\end{array}$ & Endoscopic treatment for gastrointestinal neoplasia (EMR/ & All routine diagnostic endoscopy \\
Biliary sepsis & ESD) & All surveillance and follow-up endoscopy (Barrett's oesophagus/polyp/ \\
Foreign body & IBD/gastric intestinal metaplasia/history of GI cancer) & Therapeutic endoscopy for non-cancer disease \\
Gastrointestinal obstruction requiring stenting & Small bowel enteroscopy for occult GI bleeding & Other ERCP cases-asymptomatic stones; therapy for chronic pancreatitis; \\
GI access for urgent feeding & metal stent removal/change; ampullectomy follow-up & EUS for diagnosis of benign condition \\
& & ERCP for non-malignant conditions \\
& & Endoscopic therapy for benign GI disorders (bariatric, GORD)
\end{tabular}

EMR, endoscopic mucosal resection; ERCP, endoscopic retrograde cholangiopancreatography; ESD, endoscopic submucosal dissection; EUS, endoscopic ultrasonography; GORD, gastro-oesophageal reflux disease; IBD, inflammatory bowel disease.

control measures and adherence to use of personal protective equipment. Most Asian countries adopted a policy of suppression to reduce the epidemic of COVID-19 through case identification, contact tracing and hospitalisation, and had vigorous strategies for population-wide social distancing. ${ }^{17}$ According to the prediction model of the Imperial College COVID-19 response team, a suppression policy can significantly reduce mortality and the stress on hospital care capacity. ${ }^{17}$ However, it will require sustainability until a vaccine is available.

We recommend deferring all elective endoscopies during the COVID-19 outbreak until the pandemic is over. This strategy helps to preserve the surge capacity for hospitals to manage a massive number of suspected or confirmed cases of COVID19. ${ }^{151618}$ Moreover, this will safeguard the potential transmission of COVID-19 between patients and to healthcare providers, especially at the beginning of the COVID-19 outbreak. ${ }^{16}{ }^{18} \mathrm{It}$ will also allow time for healthcare providers at the endoscopy centre to receive appropriate education and training on infection control measures. A retrospective case series from Iran reported on four surgical patients who developed severe complications after elective surgery in the first few weeks of COVID-19. All showed either clinical signs or tested positive for COVID-19, and three out of four patients died. ${ }^{19}$ The endoscopy centre should keep a record of patients with deferred endoscopy appointments and rearrange their appointments according to the situation of the COVID-19 outbreak. Table 1 shows the list of elective procedures that could be deferred until further notice.

For patients who require semi-urgent endoscopic procedures, clinicians should decide case by case on the need and indications, and those indicated should be performed as urgent endoscopic procedures (table 1).

\section{Statement 3. Urgent endoscopies should be performed by strategically assigned staff to minimise concomitant exposure}

During the COVID-19 outbreak, recommended indications for urgent endoscopy are limited to acute gastrointestinal bleeding, biliary sepsis, gastrointestinal obstruction requiring stenting or dilatation, management of gastrointestinal perforations and leakage, foreign body retrieval and establishment of access for enteral nutrition (table 1). Where urgent endoscopies are necessary, we recommend keeping the number of staff to a minimum, with preferably one experienced endoscopist and two nurses for each endoscopy room. Ample time should be allowed for infection control measures before and after endoscopy. The same team of endoscopy staff should serve the same room for the whole session.

Table 2 Type of endoscopy procedures in relation to the use of PPE (standard or enhanced), manpower and frequency of gown down

\begin{tabular}{|c|c|c|c|c|c|c|}
\hline Procedure & AGP & $\begin{array}{l}\text { Standard PPE for non-suspected/ } \\
\text { test negative cases }\end{array}$ & $\begin{array}{l}\text { Enhanced PPE for high risk/ } \\
\text { confirmed COVID-19 }\end{array}$ & $\begin{array}{l}\text { Endoscopist } \\
\text { manpower }\end{array}$ & $\begin{array}{l}\text { Endoscopy nurses } \\
\text { manpower }\end{array}$ & Frequency of gown down \\
\hline OGD & $\begin{array}{l}\text { To be } \\
\text { determined }\end{array}$ & $\begin{array}{l}\text { Surgical mask or N95 } \\
\text { Blue isolation gown } \\
\text { Gloves } \\
\text { Standard endoscopy room }\end{array}$ & $\begin{array}{l}\text { N95 } \\
\text { Blue isolation gown } \\
\text { Gloves } \\
\text { Goggles or face shield } \\
\text { Negative pressure room }\end{array}$ & $\begin{array}{l}1 \text { (at specialist } \\
\text { level) }\end{array}$ & 2 & $\begin{array}{l}\text { Mask: end of each session } \\
\text { Gown: change when } \\
\text { contaminated } \\
\text { Gloves: after each case }\end{array}$ \\
\hline Colonoscopy & $\begin{array}{l}\text { To be } \\
\text { determined }\end{array}$ & $\begin{array}{l}\text { Surgical mask or N95 } \\
\text { Blue isolation gown } \\
\text { Gloves } \\
\text { Standard endoscopy room }\end{array}$ & $\begin{array}{l}\text { N95 } \\
\text { Blue isolation gown } \\
\text { Gloves } \\
\text { Goggles or face shield } \\
\text { Negative pressure room }\end{array}$ & $\begin{array}{l}1 \text { (at specialist } \\
\text { level }\end{array}$ & 2 & $\begin{array}{l}\text { Mask: end of each session } \\
\text { Gown: change when } \\
\text { contaminated } \\
\text { Gloves: after each case }\end{array}$ \\
\hline ERCP & $\begin{array}{l}\text { To be } \\
\text { determined }\end{array}$ & $\begin{array}{l}\text { Surgical mask or N95 } \\
\text { Blue isolation gown } \\
\text { Gloves } \\
\text { Standard endoscopy room }\end{array}$ & $\begin{array}{l}\text { N95 } \\
\text { Blue isolation gown } \\
\text { Gloves } \\
\text { Goggles or face shield } \\
\text { Negative pressure room (with enough } \\
\text { space and X-ray shielding) }\end{array}$ & $\begin{array}{l}1 \text { (at specialist } \\
\text { level) }\end{array}$ & 2 & $\begin{array}{l}\text { Mask: end of each session } \\
\text { Gown: change when } \\
\text { contaminated } \\
\text { Gloves: after each case }\end{array}$ \\
\hline Bronchoscopy & Yes & $\begin{array}{l}\text { N95 } \\
\text { Blue isolation gown } \\
\text { Gloves } \\
\text { Goggles or face shield } \\
\text { Negative pressure room }\end{array}$ & $\begin{array}{l}\text { N95 } \\
\text { Blue isolation gown } \\
\text { Gloves } \\
\text { Goggles or face shield } \\
\text { Negative pressure room }\end{array}$ & $\begin{array}{l}1 \text { (at specialist } \\
\text { level) }\end{array}$ & 2 & $\begin{array}{l}\text { Mask: end of each session } \\
\text { Gown: change when } \\
\text { contaminated } \\
\text { Gloves: after each case }\end{array}$ \\
\hline
\end{tabular}

AGP, aerosol generating procedure; ERCP, endoscopic retrograde cholangiopancreatography; OGD, oesophagogastroduodenoscopy; PPE, personal protective equipment. 


\section{Statement 4. Resource reallocation for staff and medical equipment is recommended to prepare for a surge in healthcare demand}

The hospital system will undergo major stress due to a surge in the demand for the management of suspected and confirmed cases of COVID-19. As a result, endoscopy centres should rationalise and prioritise the allocation of resources, including endoscopists, nurses, healthcare providers and medical equipment. ${ }^{20}$ All healthcare providers working at the endoscopy centre should receive appropriate education and training on infection control measures, including hand hygiene and use of personal protective equipment (PPE). ${ }^{21} 22$ The endoscopy centre should arrange designated gown up and gown down areas. The supply of medical equipment, especially PPE, will be limited during the pandemic.

\section{Statement 5. Regular monitoring of supply and use of personal protective equipment (PPE) is necessary to adjust endoscopy service and uphold morale of staff}

The use of medical supplies should be carefully planned. Administrators of the endoscopy centre should regularly communicate with the hospital administration about the supply and logistics of medical equipment and PPE. The stock and use of consumables, PPE and other equipment should be monitored daily to allow better planning of service and to avoid inadequate supply of PPE, which may jeopardise safety and morale of staff. Conservation of PPE is critical and only essential personnel should be present during procedures (table 2).

\section{Statement 6. Healthcare workers should practise standard infection control for endoscopy}

SARS-CoV-2 has been shown to be transmitted indirectly through contaminated surfaces and fomites, and survival of virus on surfaces can last for hours to days. ${ }^{23}$ Similarly, SARS-CoV-2 survival has been reported in confined public spaces, including restrooms, elevators and door knobs. ${ }^{24}$ All endoscopists, nurses and healthcare providers should receive training on infection control and appropriate use of PPE during endoscopy. ${ }^{21} 222526$ Standard hand hygiene procedures before and after each case should be practised. Ethanol (62-71\% concentration), 2\% glutaraldehyde and $0.1-0.5 \%$ sodium hypochlorite are commonly used as disinfectants and can reduce the concentrations of coronavirus within $1 \mathrm{~min}$ of exposure time. ${ }^{27}$ Effective hand hygiene decreases the risk of transmission and was proved to be beneficial during SARS. ${ }^{28}$ Universal hand washing and the use of alcoholbased hand rubs on entering and leaving endoscopy rooms are highly recommended.

We recommend the use of PPE according to risk stratification (table 2). The definition of a suspected, probable and confirmed case is listed by WHO. ${ }^{2}$ For patients defined as suspected, probable or confirmed COVID-19, enhanced PPE should be practised during endoscopy, including the use of a N95 mask; isolation gown with water resistance; head cover; eye protection and face shield. ${ }^{25} 2629$ The procedure should be conducted in negative pressure room when available (see statement 9).

For patients who are FTOCC negative and not suspected to have COVID-19, healthcare providers should perform endoscopy with PPE, including a face mask; isolation gown with water resistance; eye protection. As endoscopy may be an aerosolgenerating procedure, endoscopists should be allowed to select the most appropriate PPE for the procedure. Interactions with patients, including informed consent and checking vital signs,

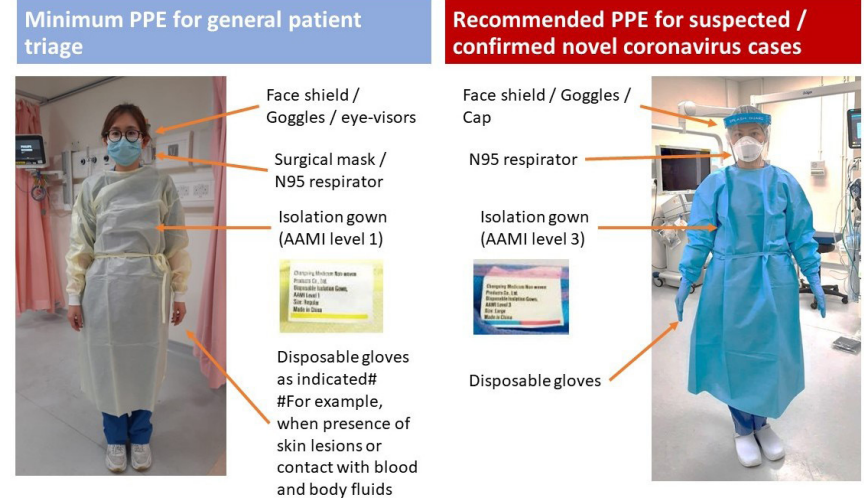

Figure 2 Recommended PPE for general patient triage and handling suspected COVID-19 cases. AAMI, Association for the Advancement of Medical Instrumentation; PPE, personal protective equipment. Image courtesy of the Hospital Authority of Hong Kong.

should be performed while maintaining some distance, and with rigorous hand washing before and after interactions.

\section{Statement 7. Healthcare workers should receive adequate training on gowning and removal of PPE}

Many health workers, including endoscopists, nurses, healthcare workers and anaesthetists, work in endoscopy suites, with different types of procedures being performed daily. There is a certain risk of exposing staff to respiratory, oropharyngeal and faecal secretions. Furthermore, aggressive suctioning and multiple catheter exchange via endoscope working channels may expose staffs to splashes of secretion. ${ }^{30}$ Microorganisms have been detected on the walls of endoscopy suite and postoperative recovery areas. ${ }^{31}$ During the SARS epidemic, $21 \%$ of people affected were healthcare workers. ${ }^{32}$ The grouping of many patients and healthcare workers at endoscopy can put them at risk of human to human transmission. For patients with COVID-19 who require endoscopic procedures under general anaesthesia, anaesthesis should be conducted by a designated team while other members of the endoscopy team should stay outside the room. The anaesthetic procedure should be performed with all healthcare providers in full PPE. ${ }^{33}$ Biopsy samples obtained from the infected person can also be a source of infection as active viral replication was identified during the SARS pandemic in 2003. ${ }^{8}$ Hence, all specimen from patients with COVID-19 should be handled with extra precaution and with appropriate protective equipment. Training should be provided for all staff for PPE gowning and downing. Figure 2 illustrates the typical PPE used in our unit in Hong Kong.

\section{Statement 8. Extra precaution is recommended during colonoscopies as prolonged faecal shedding of SARS-CoV-2 can occur}

Although the risk of faecal transmission for SARS-Cov-2 is not clear, it remains plausible as SARS-CoV-2 has been detected in the stool of patients with and without symptoms, and viral shedding occurs. ${ }^{9-12}$ It may also persist despite negative results in the respiratory tract. This can result in viral transmission via aerosolisation and faecal-oral route of contamination. ${ }^{34} \mathrm{~A}$ recent study showed that there is prolonged presence of SARS-Cov-2 viral RNA in faecal samples for up to 47 days after onset of the first symptoms. ${ }^{35}$ As endoscopes are often affected by gut flora, this could pose a risk to endoscopists, nursing staff and other endoscopy staff and could also be a vector for potential 
transmission to other patients. ${ }^{3637}$ Therefore, it is important for staff performing colonoscopies to aware of this potential risk, and colonoscopy should be considered a high-risk procedure and careful decontamination procedures vigilantly performed (see statement 10).

\section{Statement 9. Endoscopies should be performed in a negative pressure room when available with strict isolation precautions in suspected or confirmed cases of COVID-19}

For suspected, probable and confirmed COVID-19 cases, ideally we recommend performance of endoscopy in a negative pressure room. As most endoscopy units may not have a negative pressure room, the procedure can be performed in a venue outside the endoscopy centre, with negative pressure in the operation theatre, for example, or in a room with better ventilation. In the endoscopy centre, it is important to keep all patients at an appropriate distance from each other (two metres is recommended) while considering each facility's situation and capacity. Care givers or relatives of patients are strictly prohibited from entering the endoscopy department except in special circumstances in which patients require specific assistance.

\section{Statement 10. Disinfection policy for endoscopy rooms and reprocessing of instruments should be enhanced}

The standard of disinfection and reprocessing of endoscopy instruments should be practised according to American Society for Gastrointestinal Endoscopy and European Society of Gastrointestinal Endoscopy guidelines. ${ }^{2526}$ Each endoscopy department should have a detailed plan for cases of non-COVID-19 and suspected or confirmed COVID-19. Standard room disinfection should be conducted at the end of the session in rooms where non-COVID or low-risk patients had endoscopy. For patients with suspected or confirmed COVID-19 who require emergency endoscopy, the endoscopic procedure should be performed at the end of the session and the room should be cleaned after these procedures with staff using appropriate PPE. The disinfection and reprocessing of the endoscope and instruments used for a patient with COVID-19 will be similar to those used in standard practice. ${ }^{2526}$ All disposable devices used for a patient with COVID-19 should not be re-used. If treatment of patients with COVID-19 is performed in negative pressure rooms, a delay of $30 \mathrm{~min}$ is recommended before a new patient enters the room. Although no cases of endoscope-related COVID-19 transmission have been reported, this risk exists, especially in view of previous experience with hepatitis $\mathrm{B}$ and $\mathrm{C}$ viruses. It is likely that current endoscope disinfection techniques are sufficient.

\section{Statement 11. Stepwise resumption of elective endoscopy services should be guided by control of COVID-19 in the local community, availability of manpower and equipment supply}

With steady increase in the number of confirmed cases of COVID-19 among different countries and cities worldwide, it is difficult to determine the most appropriate time to resume regular service at endoscopy centres. The Imperial College COVID-19 response team predicted that suppression strategies will need adaptive triggering once rebound occurs. ${ }^{17}$ It is likely that most countries will adopt a time-bound approach in the resumption of partial or full service depending on the following factors: (1) the number and epidemic curve of confirmed COVID-19 cases; (2) the availability of medical equipment, including appropriate PPE; and (3) the accumulated volume of postponed endoscopy cases. Some non-urgent procedures are of higher priority for resumption and may need to be performed,
Table 3 Provision of endoscopy service during COVID-19 pandemic

\begin{tabular}{|c|c|c|}
\hline $\begin{array}{l}\text { COVID-19 in the } \\
\text { community }\end{array}$ & PPE supply & Endoscopy service \\
\hline $\begin{array}{l}\text { Exponential increase in } \\
\text { new cases of COVID-19 }\end{array}$ & $\begin{array}{l}\text { Critical } \\
\text { (reserve }<7 \\
\text { days) }\end{array}$ & $\begin{array}{l}\text { Urgent endoscopy only } \\
\text { Semi-urgent endoscopy - withhold } \\
\text { Elective endoscopy - withhold }\end{array}$ \\
\hline $\begin{array}{l}\text { Rapid increase in new } \\
\text { cases of COVID-19 }\end{array}$ & $\begin{array}{l}\text { Very low } \\
\text { (reserve }<4 \\
\text { weeks) }\end{array}$ & $\begin{array}{l}\text { Urgent endoscopy only } \\
\text { Semi-urgent endoscopy - to be individualised } \\
\text { Elective endoscopy - withhold }\end{array}$ \\
\hline $\begin{array}{l}\text { Down trend in new } \\
\text { cases of COVID-19 }\end{array}$ & $\begin{array}{l}\text { Suboptimal } \\
\text { (reserve 4-8 } \\
\text { weeks) }\end{array}$ & $\begin{array}{l}\text { Urgent endoscopy - full capacity } \\
\text { Semi-urgent endoscopy - full capacity } \\
\text { Elective endoscopy - resumed with 50\% } \\
\text { capacity }\end{array}$ \\
\hline $\begin{array}{l}\text { No new cases of } \\
\text { COVID-19 diagnosed } \\
\text { for at least } 2 \text { weeks }\end{array}$ & $\begin{array}{l}\text { Normal } \\
\text { (12 weeks } \\
\text { reserve) }\end{array}$ & $\begin{array}{l}\text { Urgent endoscopy - full capacity } \\
\text { Semi-urgent endoscopy - full capacity } \\
\text { Elective endoscopy - full capacity }\end{array}$ \\
\hline
\end{tabular}

$P P E$, personal protective equipment.

such as cancer evaluations and evaluation of significant symptoms. We recommend that endoscopy centres resume an elective endoscopy service in a stepwise manner in phases (table 3). For example, in the initial phase the daily volume of endoscopic procedures should be $50 \%$ of the normal capacity. The situation may also change with a sudden increase in COVID-19 cases, limitation of PPE and other medical supplies, and fatigue or limitation of healthcare providers. The administrators of endoscopy centres should have close and regular communication with the hospital management team and closely monitor the outbreak for any rapid change in plan to keep a sustainable and effective endoscopy service.

\section{Author affiliations}

${ }^{1}$ Department of Surgery, The Chinese University of Hong Kong, Hong Kong, Hong Kong

${ }^{2}$ Department of Medicine and Therapeutics, Institute of Digestive Disease, State Key Laboratory of Digestive Disease, LKS Institute of Health Sciences, The Chinese University of Hong Kong, Hong Kong, Hong Kong

${ }^{3}$ Digestive Disease Center, Showa University, Northern Yokohama Hospital, Yokohama, Japan

${ }^{4}$ Asian Healthcare Foundation, Asian Institute of Gastroenterology, Hyderabad, Andhra Pradesh, India

${ }^{5}$ Department of Gastroenterology and Hepatology, General Hospital of Chinese PLA, Beijing, China

${ }^{6}$ Digestive Endoscopy Center, CHA Bundang Medical Center, CHA University, Seoul, Republic of Korea

${ }^{7}$ Department of Medicine, Yong Loo Lin School of Medicine, National University of Singapore, Singapore

${ }^{8}$ School of Medicine, The University of Queensland, Brisbane, Queensland, Australia

${ }^{9}$ Division of Gastroenterology, Queen Elizabeth II Jubilee Hospital, Brisbane,

Queensland, Australia

${ }^{10}$ Department of Internal Medicine, College of Medicine, National Taiwan University,

Taipei, Taiwan

${ }^{11}$ Department of Medicine, Chulalongkorn University, Bangkok, Thailand

${ }^{12}$ Department of Internal Medicine, National Taiwan University Hospital and National Taiwan University College of Medicine, Taipei, Taiwan

${ }^{13}$ Faculty of Medicine, University of Malaya, Kuala Lumpur, Malaysia

${ }^{14}$ Asan Medical Center, Songpa-gu, Seoul, Republic of Korea

${ }^{15}$ Department of Gastroenterology and Hepatology, University of Malaya, Kuala Lumpur, Malaysia

${ }^{16}$ Division of Gastroenterology and Hepatology, The Jikei University School of Medicine, Tokyo, Japan

${ }^{17}$ Department of Endoscopy, The Jikei University School of Medicine, Tokyo, Japan

${ }^{18}$ Oita University, Oita, Japan

Twitter David G Hewett @dghewett

Contributors PWYC, SCN and FKLC contributed to the formulation of statements, coordination of the expert endoscopists and drafting of the manuscript. $\mathrm{HI}$, DNR, ELH, JYC, LH, DGH, H-MC, RR, H-PW, SHH, DWS, K-LG and HT are expert endoscopists who commented on the statements and manuscript. FKLC and SK are co-senior authors and act as guarantors. 
Funding The authors have not declared a specific grant for this research from any funding agency in the public, commercial or not-for-profit sectors.

Competing interests SK is president of the Asian Pacific Society of Digestive Endoscopy (APSDE); HT is vice president of APSDE; PWYC, H-PW, RR, SHH are serving as councillors of APSDE.

Patient and public involvement Patients and/or the public were not involved in the design, or conduct, or reporting, or dissemination plans of this research.

Patient consent for publication Not required.

Provenance and peer review Not commissioned; internally peer reviewed.

Data availability statement There are no data in this work.

Open access This is an open access article distributed in accordance with the Creative Commons Attribution Non Commercial (CC BY-NC 4.0) license, which permits others to distribute, remix, adapt, build upon this work non-commercially, and license their derivative works on different terms, provided the original work is properly cited, appropriate credit is given, any changes made indicated, and the use is non-commercial. See: http://creativecommons.org/licenses/by-nc/4.0/.

\section{ORCID iDs}

Philip Wai Yan Chiu http://orcid.org/0000-0001-9292-112X

Siew C Ng http://orcid.org/0000-0002-6850-4454

David G Hewett http://orcid.org/0000-0002-4529-3543

Han-Mo Chiu http://orcid.org/0000-0003-2786-8056

Francis K L Chan http://orcid.org/0000-0001-7388-2436

\section{REFERENCES}

1 WHO. Coronavirus disease (COVID-2019) situation reports. situation report - 51, 2020. Available: https://www.who.int/docs/default-source/coronaviruse/situationreports/20200311-sitrep-51-covid-19.pdf?sfvrsn=1ba62e57_10

2 WHO. Coronavirus disease (COVID-2019) situation reports. Situation report - 64, 2020. Available: https://www.who.int/docs/default-source/coronaviruse/situationreports/20200324-sitrep-64-covid-19.pdf?sfvrsn=703b2c40_2

3 Guan WJ, ZY N, Hu Y, et al. China medical treatment expert group for COVID-19. clinical characteristics of coronavirus disease 2019 in China. N Eng/ J Med 2020. [Epub ahead of print: 28 Feb 2020].

4 Wang D, Hu B, Hu C, et al. Clinical characteristics of 138 hospitalized patients with 2019 novel coronavirus-infected pneumonia in Wuhan, China. JAMA 2020. doi:10.1001/jama.2020.1585. [Epub ahead of print: 07 Feb 2020].

5 Huang C, Wang Y, Li X, et al. Clinical features of patients infected with 2019 novel coronavirus in Wuhan, China. Lancet 2020;395:497-506.

6 Chen N, Zhou M, Dong X, et al. Epidemiological and clinical characteristics of 99 cases of 2019 novel coronavirus pneumonia in Wuhan, China: a descriptive study. Lancet 2020;395:507-13.

7 Wong T-wai, Lee C-kei, Tam W, et al. Cluster of SARS among medical students exposed to single patient, Hong Kong. Emerg Infect Dis 2004;10:269-76.

8 Leung WK, To K-F, Chan PKS, et al. Enteric involvement of severe acute respiratory syndrome-associated coronavirus infection. Gastroenterology 2003:125:1011-7.

9 Gu J, Han B, Wang J. COVID-19: gastrointestinal manifestations and potential fecaloral transmission. Gastroenterology 2020. doi:10.1053/j.gastro.2020.02.054. [Epub ahead of print: 03 Mar 2020]

10 Song Y, Liu P, Shi XL, et al. SARS-CoV-2 induced diarrhoea as onset symptom in patient with COVID-19. Gut 2020:69:1143-4.

11 Zhang J, Wang S, Xue Y. Fecal specimen diagnosis 2019 novel coronavirus-infected pneumonia. J Med Virol 2020. doi:10.1002/jmv.25742. [Epub ahead of print: 03 Mar 2020].

12 Xiao $F$, Tang M, Zheng $\mathrm{X}$, et al. Evidence for gastrointestinal infection of SARS-CoV-2. Gastroenterology 2020. doi:10.1053/j.gastro.2020.02.055. [Epub ahead of print: 03 Mar 2020].

13 American College of Gastroenterology Joint GI Society Message on COVID 19. Available: https://gi.org/2020/03/15/joint-gi-society-message-on-covid-19/
14 British Society of Gastroenterology. Endoscopy activity and COVID-19: BSG and JAG guidance. Available: https://www.bsg.org.uk/covid-19-advice/endoscopy-activity-andcovid-19-bsg-and-jag-guidance/

15 Wong ATY, Chen H, Liu S-H, et al. From SARS to avian influenza preparedness in Hong Kong. Clin Infect Dis 2017;64:S98-104.

16 Ho AS, Sung JJY, Chan-Yeung M. An outbreak of severe acute respiratory syndrome among hospital workers in a community hospital in Hong Kong. Ann Intern Med 2003;139:564-7.

17 Fergurson NM. Impact of non-pharmaceutical interventions (NPIs) to reduce COVID-19 mortality and healthcare demand. Report 9. Imperial College London, 2020.

18 Ng K, Poon BH, Kiat Puar TH, et al. COVID-19 and the risk to health care workers: a case report. Ann Intern Med 2020. doi:10.7326/L20-0175. [Epub ahead of print: 16 Mar 2020].

19 Aminian A, Safari S, Razeghian-Jahromi A, et al. COVID outbreak and surgical practice: unexpected fatality in perioperative period. Ann Surgery 2020.

$20 \mathrm{Ji} \mathrm{Y,} \mathrm{Ma} \mathrm{Z,} \mathrm{Peppelenbosch} \mathrm{MP,} \mathrm{et} \mathrm{al.} \mathrm{Potential} \mathrm{association} \mathrm{between} \mathrm{COVID-19} \mathrm{mortality}$ and health-care resource availability. Lancet Glob Health 2020;8:e480.

21 Repici A, Maselli R, Colombo M, et al. Coronavirus (COVID-19) outbreak: what the department of endoscopy should know. Gastrointest Endosc 2020. doi:10.1016/j. gie.2020.03.019. [Epub ahead of print: 13 Mar 2020].

22 Soetikno R, Teoh AY, Kaltenbach T, et al. Consideration in performing endoscopy during the COVID-19 pandemic. Gastrointest Endosc 2020.

23 van Doremalen N, Bushmaker T, Morris DH, et al. Aerosol and surface stability of SARS-CoV-2 as compared with SARS-CoV-1. N Eng/ J Med 2020. doi:10.1056/ NEJMc2004973. [Epub ahead of print: 17 Mar 2020].

24 Cai J, Sun W, Huang J, et al. Indirect virus transmission in cluster of COVID-19 cases, Wenzhou, China, 2020. Emerg Infect Dis 2020;26.

25 ASGE Quality Assurance in Endoscopy Committee, Calderwood AH, Day LW, et al. ASGE guideline for infection control during Gi endoscopy. Gastrointest Endosc 2018;87:1167-79

26 Beilenhoff $\mathrm{U}$, Biering $\mathrm{H}$, Blum $\mathrm{R}$, et al. Reprocessing of flexible endoscopes and endoscopic accessories used in gastrointestinal endoscopy: position statement of the European Society of Gastrointestinal Endoscopy (ESGE) and European Society of Gastroenterology Nurses and Associates (ESGENA) - Update 2018. Endoscopy 2018:50:1205-34.

27 Siddharta A, Pfaender S, Vielle NJ, et al. Virucidal activity of World Health Organization-recommended formulations against enveloped viruses, including Zika, Ebola, and emerging coronaviruses. J Infect Dis 2017;215:902-6.

28 Wong T-W, Tam WW-S. Handwashing practice and the use of personal protective equipment among medical students after the SARS epidemic in Hong Kong. Am J Infect Control 2005;33:580-6.

29 Kilinc FS. A review of isolation gowns in healthcare: fabric and gown properties. J Eng Fiber Fabr 2015;10:180-90.

30 Perisetti A, Garg S, Inamdar S, et al. Role of face mask in preventing bacterial exposure to the endoscopist's face. Gastrointest Endosc 2019;90:859.

31 Johnston ER, Habib-Bein N, Dueker JM, et al. Risk of bacterial exposure to the endoscopist's face during endoscopy. Gastrointest Endosc 2019;89:818-24.

32 Chang D, Xu H, Rebaza A, et al. Protecting health-care workers from subclinical coronavirus infection. Lancet Respir Med 2020;8:e13.

33 LK T, Ang LS, Foong TW, et al. What we do when a COVID-19 patient needs an operation: operating room preparation and quidance. Can J Anaesth 2020.

34 Kampf G, Todt D, Pfaender S, et al. Persistence of coronaviruses on inanimate surfaces and their inactivation with biocidal agents. J Hosp Infect 2020;104:246-51.

35 Wu Y, Guo C, Tang L, et al. Prolonged presence of SARS-CoV-2 viral RNA in faecal samples. Lancet Gastroenterol Hepatol 2020. doi:10.1016/S2468-1253(20)30083-2. [Epub ahead of print: 19 Mar 2020].

36 Kovaleva J, Peters FTM, van der Mei HC, et al. Transmission of infection by flexible gastrointestinal endoscopy and bronchoscopy. Clin Microbiol Rev 2013;26:231-54.

37 Rahman MR, Perisetti A, Coman R, et al. Duodenoscope-associated infections: update on an emerging problem. Dig Dis Sci 2019;64:1409-18. 